\title{
Miletos'tan Ele Geçen İnce Cidarlı Keramikler ve Üretim Yerleri Sorunu
}

\section{Thin Walled Pottery at Miletus and Some Observations on the Places of Production}

\section{Reyhan ŞAHİN*}

$\ddot{O}_{z:}$ İtalya'da MÖ II. yüzyıl sonlarından MS III. yüzyıl sonlarına kadar üretilmiş olan ince cidarlı keramikler özellikle Erken İmparatorluk Dönemi'nden itibaren Küçük Asya'nın batı kıyılarındaki merkezlerde de karşımıza çıkmaktadır. Bouleuterion'un batısındaki WB59 (Westlich des Bouleuterion) ve tiyatro terasının güneyindeki S61 (Südschnitt) açmaları, Heroon III, Heroon I, Güney Hamamlar ve Piskoposluk Sarayı'ndaki kazılarda ele geçen buluntular Miletos'un ince cidarlı keramikleri ile ilgili önemli bilgiler sağlamaktadır. Erken İmparatorluk Dönemi buluntularının büyük çoğunluğunu elips ya da konik gövdeli içki kapları oluşturmaktadır. Öte yandan J. Hayes'in "Boccalina a Collarino" tipi olarak adlandırdığı maşrapaların huni formundaki ağıza sahip örnekleri MS II.-III. yüzyıla tarihlenen buluntu topluluklarında karşımıza çıkmaktadır. Form repertuvarı ağırlıklı olarak Batı Anadolu kıyılarındaki merkezlerde üretilmiş olan buluntularla karşılaştırma yapmaya imkan vermektedir. Aynı zamanda elips ya da konik gövdeli içki kaplarının önemli bir kısmı Meander Bölgesi kil özelliği göstermektedir. Erken İmparatorluk Dönemi’ne tarihlenen örnekler arasında Knidos üretimi parmak baskılı kase, Kuzey Ege üretimi olması muhtemel "Urnetta a Colarino" tipi maşrapa bulunmaktadır. Boccalino tipi Maşrapaların MS II.-III. yüzyıla tarihlenen örnekleri arasında Phokaia üretimi olduğu tespit edilen bir parça mevcuttur. İtalya üretimi ince cidarlı kapların İonia Bölgesi genelinde olduğu gibi Miletos’ta da talep görmediği anlaşılmaktadır.

Anahtar sözcükkler: Ionia, Miletos, İnce Cidarlı Keramik, Geç Hellenistik Dönem Keramiği, Roma Keramiği

Abstract: Thin walled pottery was produced in Italy between the late II $^{\text {nd }}$ century B.C. to the III $^{\text {rd }}$ century A.D. Scanty examples from find spots in Western Asia Minor are extensive in Early Roman deposits. Available finds from the trenches WB59, S61 and also from Heroon III, Heroon I, the South Baths and the Bishops Palace, present an overwiew of the spectrum of thin walled pottery from Miletus. Ellipsoidal and conical beakers from the late $\mathrm{I}^{\mathrm{st}}$ century B.C. and the early $\mathrm{I}^{\text {st }}$ century A.D. form the most frequently represented group amongst finds from the early Roman Period. Boccalina a Collarina Type Jugs with a cone shaped rim are represented in deposits dating from the $\mathrm{II}^{\text {nd }}$ and $\mathrm{III}^{\text {rd }}$ century A.D. The available finds from Miletos provide a close analogy with examples from western Asia Minor. Some of the ellipsoidal and conical beakers are from a micaceaous Meander clay. Among the finds from the Early Roman Period, Cnidian carinated cups with thumb impressions and Urnetta Collarina type jugs, probably of Northern Aegean origin, were also found. Among the later types of Boccalino a Collarino jugs (with cone shaped rim) from the III ${ }^{\text {rd }}$ century A.D., an example from the Phocean workshop was identified. Available data indicates Italian thin walled pottery was not favoured in Miletus, as was the case with other cities of Ionia.

Keywords: Ionia, Miletus, Thin Walled Pottery, Late Hellenistic Pottery, Roman Pottery

\section{Giriş}

İtalya'da, Geç Cumhuriyet Dönemi'nden itibaren üretimi başlayan ince cidarlı keramiklerin en belirleyici özellikleri ince bir cidara ve sert pişmiş bir hamura sahip olmalarıdır. İnce cidarlı içki

\footnotetext{
* Dr. Öğr. Üyesi, Uludağ Üniversitesi, Fen-Edebiyat Fakültesi, Arkeoloji Bölümü, Bursa, reyhansahin@uludag.edu.tr
} 
kaplarının sigillataların tabak, kase gibi açık formlarına eşlik eden içki kaplarından oluşan bir grup olduğu zaman zaman araştırmalarda ileri sürülmüssse de (Hayes 2005, 19, 21), günümüzde ayrı bir kategori olarak sınıflandırılmaktadır. Akdeniz'in batısındaki merkezlerden ele geçen ince cidarlı keramikler konusunda en kapsamlı çalışmalar M. Vegas (Vegas 1963, 275-304), F. Mayet (Mayet 1975; Mayet 1980) ve M.T.M. Moevs (Moevs 1973) tarafından yapılmıştır (İberia ve İtalya ince cidarlı keramikleri için ayrıca bk. Carandini 1977, 25-31; Hayes 1976; Kenrick 1985; Rizzo 2003; Magdalensberg örnekleri için bk. Schindler-Kaudelka 1975). Mevcut veriler, İtalya'da üretimin başlamasının hemen ardından Ege ve Akdeniz dünyasında farklı merkezlerde de bu gruba talep olduğuna işaret etmektedir (Moevs 1973, 36). Atina Agorası (Hayes 19631964, 34; Rotroff 1997, 221), Korinthos (Slane 1990, 91) ve İskenderiye'den (Elaigne 2000, 19 vd.) ele geçen buluntular ince cidarlı keramiklerin Yunanistan ve Mısır'da Geç AgustusTiberius Dönemi'nden itibaren daha yoğun ilgi gördüklerine işaret etmektedir. Küçük Asya'da Geç Hellenistik ve Erken İmparatorluk Dönemi'nden itibaren ortaya çıkmış olan ince cidarlı kapların en geç Erken İmparatorluk Dönemi'nden itibaren Küçük Asya'daki atölyelerde üretilmeye başladıkları bilinmektedir (Kögler 2010, 340, dn. 1771). Bununla birlikte, Küçük Asya'nın batısını da içine alan Doğu Ege ve Doğu Akdeniz'den ele geçen ince cidarlı keramiklerle ilgili ayrıntılı bir çalışma bulunmamaktadır (Araştırma tarihi için bk. Gassner 1997, 155; Kögler 2010, 339 vd; Fenn 2016, 135 dn. 1367).

$\mathrm{Bu}$ çalışmada Bouleuterionun batısında 1959 yılında (WB59 açması: Westlich des Bouleuterions) ve Tiyatro Terasının güneyinde, 1961 yılında (S61 açması: Süd) yapılan kazılarda ele geçen buluntular incelenmiştir (No. 1-13). Aynı zamanda metin içinde "M" kodu ile numaralandırılmış buluntular (M1-M14); daha önce Miletos kazı raporları kapsamında yayınlanmış, fakat hassas tipolojik sınıflandırması yapılmamış olan Heroon III, Heroon I, Piskoposluk Sarayı (Bischofspalast) ve Güney Hamamlar (Südstadtthermen)'dan ele geçen örnekler için kullanılmıştır. Söz konusu ince cidarlı kaplar, metin içinde ve yazılı katalog kısmında -bulundukları yayın referans gösterilmek suretiyle- ilgili form kategorilerine dahil edilmiştir.

Birinci bölümde ince cidarlı kapların ele geçtiği buluntu toplulukları ve kap formlarının buluntu yerlerine göre dağ 1 lımı tanıtılmıştır. İkinci bölümde farklı dönemlere göre formların çeşitliği sunulmuştur. Üçüncü bölümde ise; genel olarak Küçük Asya'nın batısındaki ince cidarlı keramik repertuvarı ve üretim merkezleri değerlendirilmiştir. Böylelikle Miletos'tan farklı buluntu topluluklarından ele geçen ince cidarlı kapların form ve köken çeşitliliği ile kronolojik dağılımı Ionia ve Küçük Asya genelinde karşılaştırmalı olarak incelenmiştir.

\section{Miletos'ta İnce Cidarli Kapların Ele Geçtiği Buluntu Grupları (Fig. 1-5)}

İnce cidarlı kaplar ve ele geçtikleri buluntu topluluklarının ayrıntılı listesi Tablo 1'de yer almaktadır. Kap formlarının buluntu yerlerine göre dağılımları ise Fig. 4'teki grafikte gösterilmiştir.

WB59 Bouleuterionun Batısı (Westlich des Bouleuterions) (Fig. 2): Miletos'ta Arkaik Dönem'deki yerleşimin kapsamını anlamaya yönelik olarak Bouleuterion'un batısında kuzey ve güney Agora arasında 1959'da kazılar yapılmıştır. WB59 olarak kodlanan bu alanda Doğu-Batı Açması'nın III-V kesitinde Roma Dönemi'ne ait peristilli bir avlunun içinde Orta İmparatorluk Dönemi'ne tarihlenen bir villanın mozaik taban döşemesi tespit edilmiştir (Kleiner, MüllerWiener 1972, 66; Kossatz 1990, 63). Mozaik taban döşemesi altından ele geçen ince cidarlı kaplar ve buluntu toplulukları kazı günlükleri ışığında şu şekilde özetlenebilir:

(No. 1) WB59O: doğu-batı açması yüzey buluntularından oluşmaktadır.

(No. 2) WB59O63: doğu-batı açması- III-IV kesitinde yer alan mozaik taban döşemesinin altında yer alır. En erken buluntular Arkaik Dönem boyalı keramikleridir. Hellenistik Dönem astarlı 
keramikleri, figürlü Megara Kaseleri, figürlü terrakotta ve kandilleri kapsayan Geç HellenistikOrta İmpartorluk Dönemi buluntuları yoğundur:

Tablo 1. Kap Formları ve Ele Geçtikleri Buluntu Toplulukları

\begin{tabular}{|c|c|c|}
\hline Kap Formu & Katalog No. / Referans & Buluntu Yeri \\
\hline \multirow{2}{*}{$\begin{array}{l}\text { İçki Kabı (Elips Gövdeli) } \\
\text { Moevs 1973, Form IV }\end{array}$} & No. 1 & WB59O \\
\hline & M1: Pülz 1985, 102, Res. 3, No. 25 & Heroon III- NVIII \\
\hline \multirow{4}{*}{$\begin{array}{l}\text { İçki Kabı (Elips Gövdeli) } \\
\text { Moevs 1973, Form VII }\end{array}$} & No. 2 & WB59O63 \\
\hline & No. 3 & WB59O \\
\hline & No. 4 & WB59O72 \\
\hline & M2: Niewöhner et al. 2015a 227, Res. 80 & $\begin{array}{l}\text { Güney Hamamlar, } \\
\text { (Caldarium, Hypokaust) }\end{array}$ \\
\hline \multirow{2}{*}{$\begin{array}{l}\text { İçki Kabı (Elips Gövdeli) } \\
\text { Moevs 1973, Form IV, Form } \\
\text { VII, Form XXXV }\end{array}$} & No. 5 & WB59O35. 5 \\
\hline & No. 6 & WB590 \\
\hline $\begin{array}{l}\text { İçki Kabı (Konik Gövdeli) } \\
\text { Moevs 1973, Form XXX }\end{array}$ & No. 7 & WB59056 \\
\hline \multirow{2}{*}{$\begin{array}{l}\text { İçki Kabı (Konik Gövdeli) } \\
\text { Moevs 1973, Form XII }\end{array}$} & No. 8 & S61 21/23 \\
\hline & No. 9 & S61.47 \\
\hline $\begin{array}{l}\text { İçki Kabı (Konik Gövdeli) } \\
\text { Moevs 1973, Form XXXV }\end{array}$ & No. 10 & WB59/71 \\
\hline $\begin{array}{l}\text { Kase }(\text { Dışa Çekik Ăğıll }) \\
\text { Moevs 1973, Form XXXVIII }\end{array}$ & M3: Pülz 1985, Res. 3, No. 27 & Heroon III- NVIII \\
\hline $\begin{array}{l}\text { Kase (Dirsekli) } \\
\text { Moevs 1973, Form XXXVI }\end{array}$ & M4: Pülz 1986, 22, Res.. 3, No. 9 & Heroon I- Pithos \\
\hline $\begin{array}{l}\text { Kase (Parmak Baskill) } \\
\text { Moevs 1973, Form XXXVII) }\end{array}$ & M5: Pülz 1987,52, Res. 12, No.30 & Heroon III- S/T VI/VII \\
\hline \multirow{2}{*}{$\begin{array}{l}\text { Maşrapa (Soldatenbecher) } \\
\text { Moevs 1973, Form XVII }\end{array}$} & M6: Pülz 1987, 58, Res. 18, No. 54 & Heroon III-S/T VI/VII \\
\hline & M7: Pülz 1987, 58, Res. 18, No. 55 & Heroon III-S/T VI/VII \\
\hline \multirow{2}{*}{$\begin{array}{l}\text { Maşrapa (Boccalini a Collarino) } \\
\text { Moevs 1973, Form VII; Form VIII }\end{array}$} & M8: Pülz 1985, Res. 3, No. 28 & Heroon III-NVII \\
\hline & M9: Pülz 1987, 53, Res. 13, 37 & Heroon III-S/T VI/VII \\
\hline \multirow{2}{*}{$\begin{array}{l}\text { Maşrapa (Urnetta/Boccalino a } \\
\text { Collarino-Kuzey Ege Tipi) } \\
\text { Moevs 1973, Form XIV }\end{array}$} & M10: Pülz 1985, Res. 3, No. 29 & Heroon III-N VIII- E \\
\hline & M11: Pülz 1985, 104, Res. 5, No. 47 & $\begin{array}{l}\text { Heroon III- U VIII-X } \\
\text { VIII (Kalkgrube) }\end{array}$ \\
\hline \multirow{7}{*}{$\begin{array}{l}\text { Maşrapa } \\
\text { (Huni Ağgzll-MS II./III. yüzyıl) } \\
\text { Özyiğit 1992, 115, Res. 9b }\end{array}$} & No. 11 & S61/81 \\
\hline & No. 12 & S61/56 \\
\hline & No. 13 & S61/72 \\
\hline & No. 14 & S61/76 \\
\hline & M12: Pülz 1986, 23, Res. 4, No. 13 & Heroon I - Pithos \\
\hline & M13: Pülz 1986, 23, Res. 5, No. 18 & Heroon I - Pithos \\
\hline & M14: Niewöhner at al. 2015b, 235, Res. & Piskoposluk Sarayı \\
\hline
\end{tabular}

(No. 3) WB59O: doğu-batı açması yüzey buluntularından oluşmaktadır.

(No. 4) WB59O35: kuzey-güney açmasında, Kuzey Agorada, güneyden ilk odada yer alır (Kleiner \& Müller-Wiener 1972, 55). Buluntu topluluğunda yer alan Arkaik-Hellenistik Dönem arasına tarihlenen keramiklerin önemli bir bölümünü Geç Hellenistik Dönem'e tarihlenen astarlı keramikler, Megara kaseleri, figürlü terracotta ve kandiller oluşturmaktadır.

(No. 5) WB59056: Doğu-Batı açması I-III kesitinde, mozaik taban döşemesi seviyesinin altında yer alır. Arkaik Dönem'den Roma İmparatorluk Dönemi'ne uzanan karışık bir buluntu topluluğudur. MÖ IV. yüzyıl siyah firnisli keramikleri, Megara Kaseleri, ESC, açık renk hamurlu gün- 
lük kullanım keramiklerinden oluşan, Hellenistik-Orta İmparatorluk Dönemi buluntuları yoğunluk göstermektedir.

(No. 8) WB59O71: Doğu-Batı Açmas1- III-IV kesitinde yer alan, mozaik taban döşemesinin altındadır. Geç Hellenistik-Orta İmpartorluk Dönemi arasına tarihlenen Hellenistik Dönem mat astarlı kaplar1, Knidos Kasesi, Megara Kasesi, Batı Yamac1 dekorlu kaplar, ESB ve ESC'nin Orta İmparatorluk Dönemi formları ve bir pişmiş toprak bir figürine ait kadın başı, ele geçen buluntular arasindadir.

(No. 9) WB59O: doğu-batı açması yüzey buluntularından oluşmaktadır.

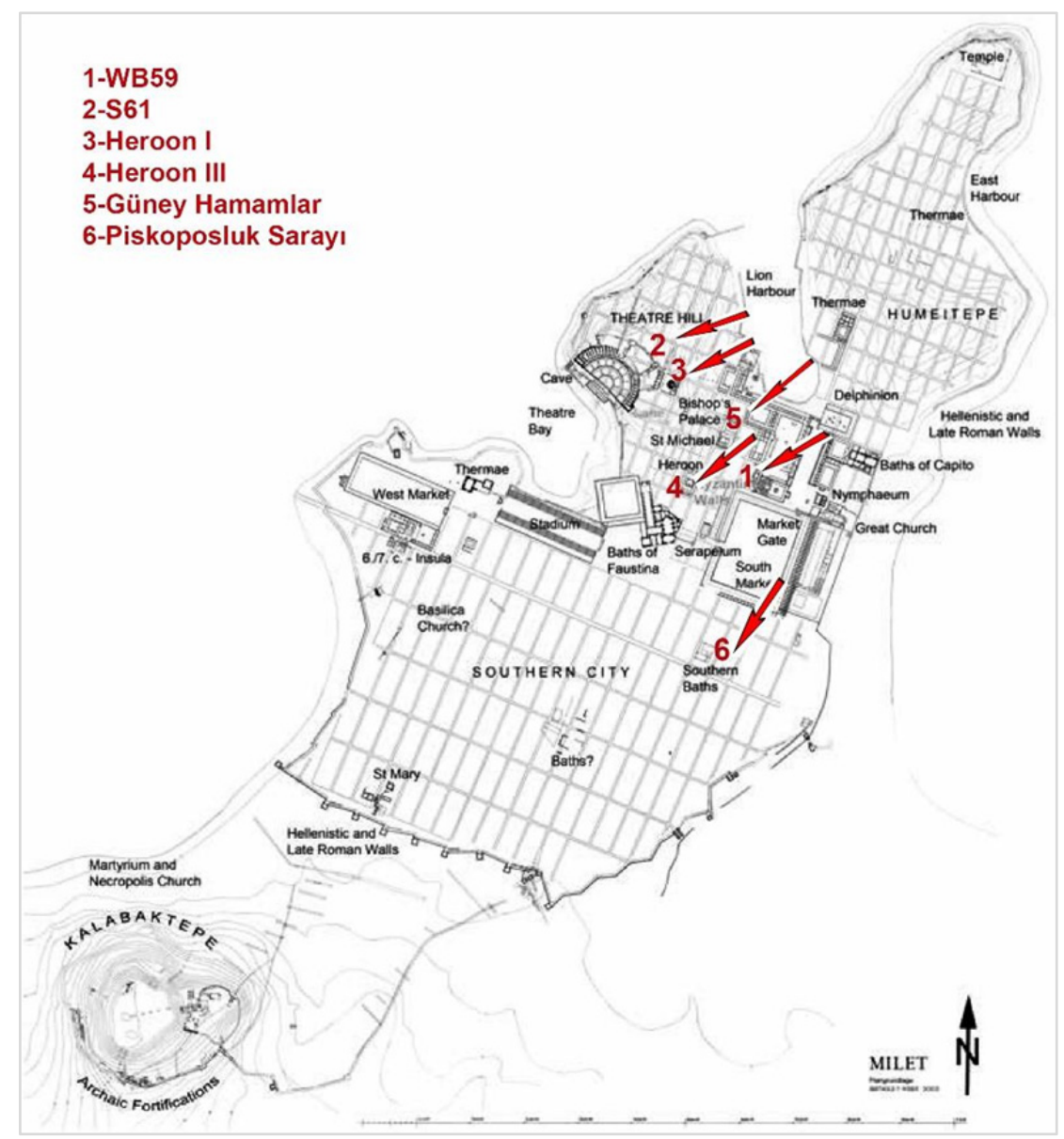

Fig. 1. İnce Cidarlı Keramiklerin Ele Geçtiği Alanlar (Harita: Berthold F. Weber)

S61 (Südschnitt) (Fig. 3): Miletos'ta Arkaik Dönem yerleşiminin kapsamını tespit etmeye yönelik olarak 1961 yılında G. Kleiner başkanlığında Tiyatro tepesindeki terasta yer alan kalenin hemen dışında kuzey ve güneyde olmak üzere iki alanda kazılar yapılmıştır. İnce cidarlı kaplar, terasın güneydeki S61 (Südschnitt)'ten ele geçmiştir. Mevcut mimari kalıntılar 1şı̆̆ında bu alanın Geç Hellenistik Dönem 'den itibaren konut alanı olarak kullanıldığ (Kleiner 1962, 46). Öte yandan S61 ile ilgili kazı kayıtları bulunmamaktadır (S61'den ele geçen Megara Kaselerini değerlendiren A. Kossatz da bu durumu dile getirmiştir bk. Kossatz 1990, 75 'te ). Bu nedenle kazı deposunda buluntu kasaları incelenerek ince cidarlı kapların ele geçtiği buluntu topluluklarının dönemsel karakteristiği üzerine bir izlenim edinilmiştir. Buna göre mevcut buluntular ve yer aldıkları buluntu toplulukları şu şekilde özetlenebilir:

(No. 6) S61 21/23: En erken buluntular MÖ IV. yüzy1l siyah firnis keramiğidir (4 parça). Buluntu topluluğu genelinde Geç Hellenistik Dönem mat astarlı keramiği belirgin bir çoğunluktadır (19 
parça). ESB ve LRC (1'er parça), sarı-yeşil sırlı Geç Bizans Dönemi sgrafito keramiği (11 parça), açık renk hamurlu günlük kullanım keramikleri (4 gövde parçası) de buluntular arasındadır.

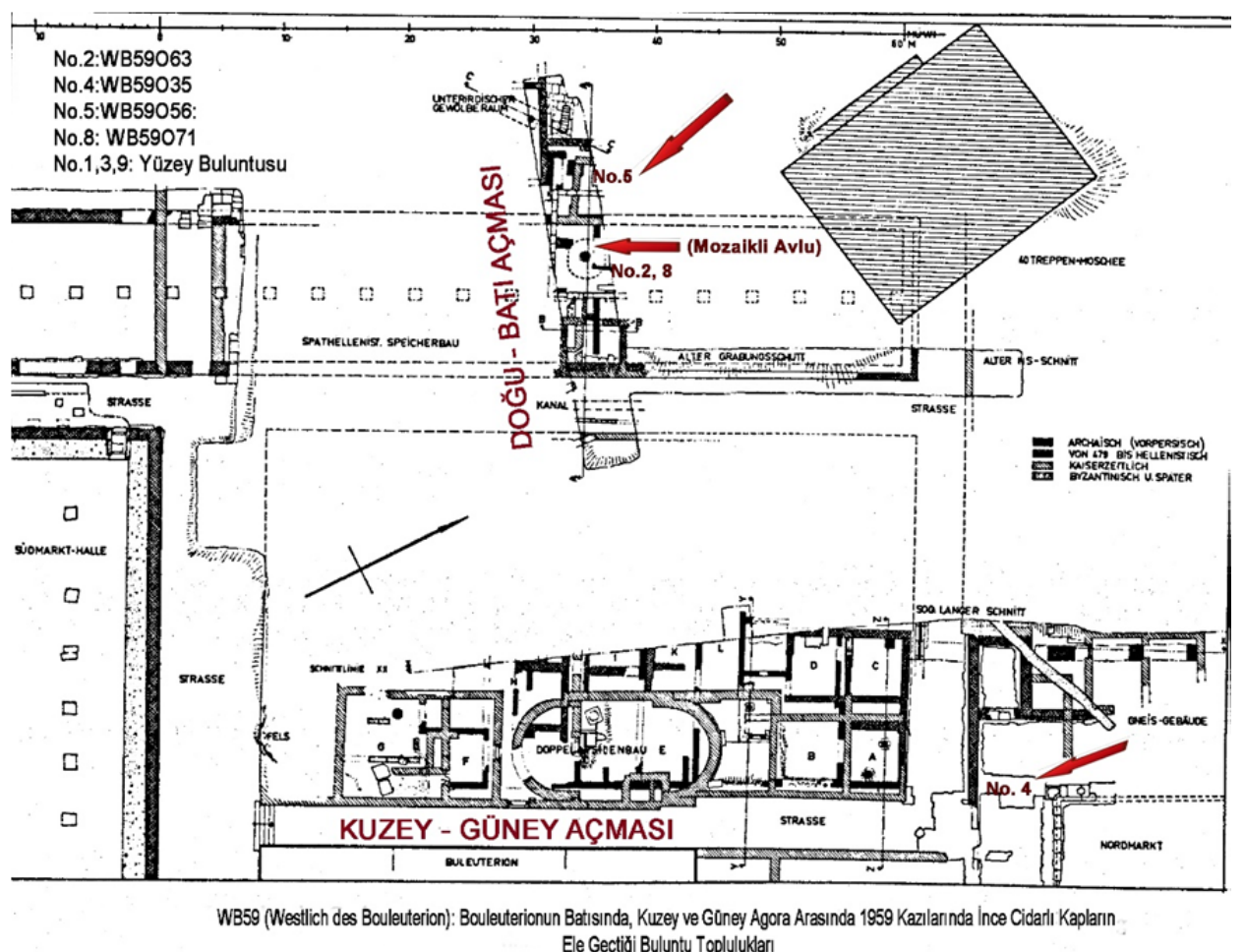

Fig. 2. WB59 Bouleuterionun Batısı (Westlich des Bouleuterions) Açma Planı ve İnce Cidarlı Kapların Ele Geçtiği Yerler (Kossatz 1990, 64, Beilage 9).

(No. 7) S61.47: Arkaik Dönem'den Geç Hellenistik Dönem aralığına tarihlenen buluntuları içerir. En erken buluntular Arkaik Dönem'den Orientalizan üslupta tabaklardır (2 parça). siyah firnisli keramiklerin MÖ IV-III. yüzyıl formları (6 parça) yanı sıra Hellenistik Dönem mat astarlı (10 parça) keramikleri, açık renk hamurlu günlük kullanım keramikleri (4 gövde parçası) ve 1 pişirme kabı da buluntular arasındadır.

(No. 10) S61/81: Arkaik Dönem'den, Geç Bizans Dönemi aralığına tarihlenen buluntuları içerir. Keramikler, Orientalizan üslup (10 parça tabak ve skyphos), kırmızı figür (2 parça), MÖ IV-III. yüzyıl siyah firnis (1 parça), beyaz zemin tekniği (2 parça lagynos), Megara Kâsesi (1 parça), Hellenistik Dönem mat astarlı keramiği (6 parça), LRC (1parça) örneklerinden oluşmaktadır. Aynı zamanda Erken Bizans Dönemi'nden bir kandil kulbu ve açık renk hamurlu günlük kullanım keramikleri de (8 gövde parçası) buluntular arasındadır.

(No. 11) S61/56: Hellenistik-Erken İmparatorluk-Geç Antik Çağ aralığına tarihlenen buluntuları içerir. En erken buluntu MÖ IV. yüzyıldan siyah firnis tekniğinde bir kaba aittir. Keramikler arasında Geç Hellenistik Dönem mat astarlı keramikleri (19 parça) ağırlıktadır. Açık renk hamurlu 1 çanak ve 1 pişirme kabı MS III.-IV. yüzyıla tarihlenmektedir.

(No. 12) S61/72: Arkaik Dönem'den, Geç Hellenistik Dönem aralığına tarihlenen buluntuları içerir. Geç Hellenistik Dönem buluntuları çoğunluktadır. Buluntular Arkaik Dönem'den Orientalizan Üslup (1 tabak parçası), MÖ IV. yüzyıl kırmızı figür tekniği (1 parça), MÖ IV. yüzyıl siyah firnis (5 parça), Megara Kâsesi (1 parça) ve Hellenistik Dönem astarlı keramiği (8 parça) örneklerinden oluşmaktadır. 
(No. 13) S61/76: Arkaik Dönem'den, Geç Hellenistik Dönem aralığına tarihlenen buluntulardan oluşur. Geç Hellenistik Dönem keramikleri çoğunluktadır. Buluntu repertuvarı ve buluntuların dönemsel dağılımı S61 /72 ile yakın benzerlik gösterir.

Heroon I: Tiyatro tepesinde, Hellenistik Dönem Heroon yapısında 1985 yılında Müller Wiener tarafından yapılan kazılarda keramik çöplüğü olarak kullanıldığg anlaşılan bir pithos bulunmuştur. (Pülz 1986, 13 20). M4, M12, M13 söz konusu pithostan ele geçmiş olan örneklerdir. Pithos içindeki kontekst Orta İmparatorluk Dönemi’ne (MS II. yüzyılın ilk yarısına) tarihlenir (Pülz 1986, 17).

Heroon III: Roma Dönemi Heroon yap1sinda 1983-1984 yılları arasinda kazılar yapılmıştır (Pülz 1985, 77-99). 1984 yılında yapılan kazılarda farklı dönemlerden kapalı buluntu kontekstlerine rastlanmıştır (Pülz 1987, 34-69). M1, M5, M6 ve M9'un ele geçtiği S/T VI/ VII, erken İmparatorluk Dönemi'ne tarihlenen buluntuları kapsamaktadır (Pülz 1987, 34). M3'ün ele geçtiği NVIII buluntu topluluğu ise MS I. yüzyıla

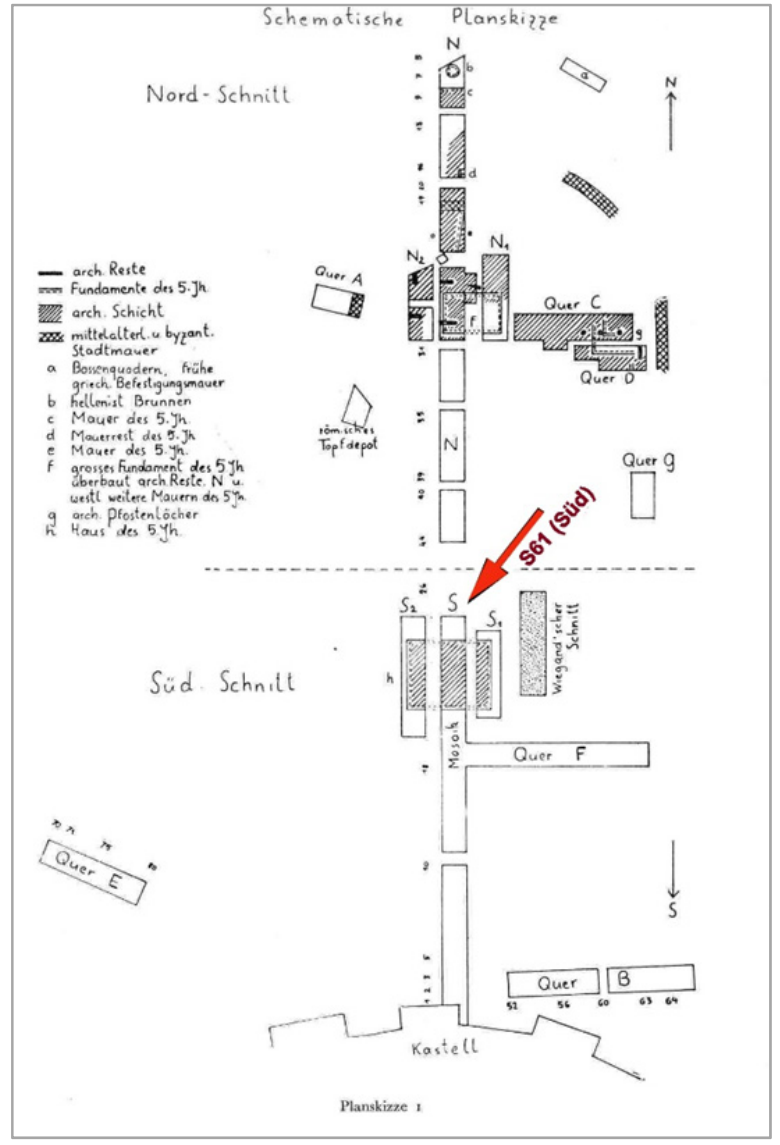

Fig. 3 S61 Güney Açma (Südschnitt) Planı (Kleiner 1972, 64, Lev. 39). tarihlenir (Pülz 1985, 78). M10-M11, yapının inşası sırasında kullanılmış olan bir kireç çukurundan (U VIII-X VIII: Kalkgrube) gelmektedir. Çukurun Heroon III'ün inşası için kullanıldıktan hemen sonra kapatılmış olduğu anlaşılmaktadır. Ele geçen buluntular Orta İmparatorluk Dönemi'ne (MS II.-III. yüzy1l) işaret etmektedir (Pülz 1985, 84).

Güney Hamamlar (Südstadtthermen): Kentin güney bölümünde yer alan Bizans Dönemi hamam yapısıdır. (M2) Kaldarium altındaki Hyposkausttan Hellenistik Dönem ve Erken Augustus Dönemi aralığına tarihlenen bir arkeolojik kontekstten ele geçmiştir (Niewöhner et al. 2015a, 227).

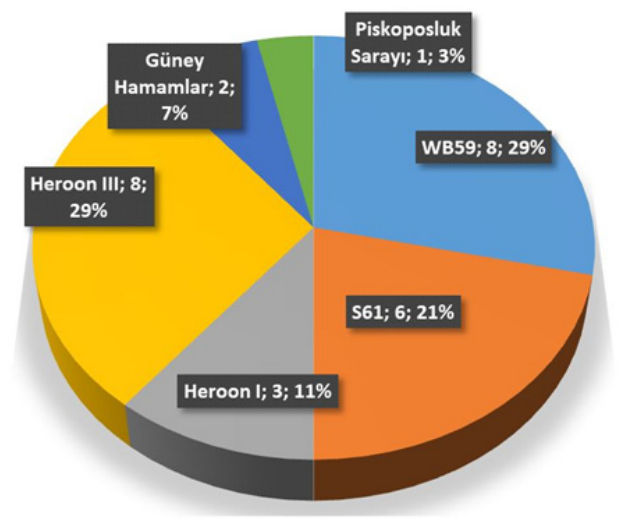

Fig. 4. Mevcut İnce Cidarlı Kapların Buluntu Yerlerine Göre Dağılımı

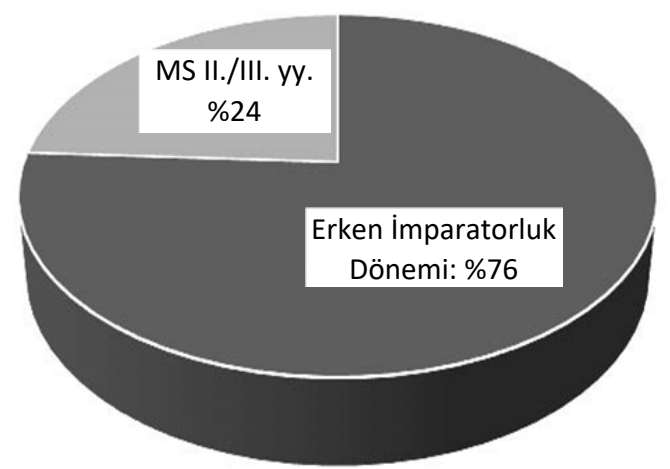

Fig. 5. Mevcut İnce Cidarlı Kapların Dönemlere Göre Dağılımı 
Piskoposluk Sarayı (Bischofspalast): (M14) yapının farklı yapı evrelerini tespit etmeye yönelik çalışmalar kapsamında komşu insulada, Geç Roma Dönemi peristilli villa yapısından ele geçmiştir (Niewöhner vd. 2015b, 187 vd.). Buluntu topluluğu ESB'ler 1şığında MS II. yüzyıl sonlarından MS III. yüzyıl ortaları arasına tarihlenmiştir (Niewöhner vd. 2015b, 228).

\section{Miletos'tan Ele Geçen İnce Cidarlı Kap Repertuvarı}

\section{Erken Roma Dönemi İnce Cidarlı Kapları \\ İçki Kapları \\ Elips Gövdeli İçki Kapları (Fig. 6, No.1-4; Tablo 1, M1-M2)}

No. 1 konveks bir ağıza ve aşağı doğru daralan bir gövdeye sahiptir. Ağızın gövdeye oranla kısa olması nedeniyle, elips gövdeli içki kabı olarak sınıflandırılabilir (Moevs 1973, 59, No. 37, Lev. 4, 57; Ricci 1985, Lev. 79, No. 5). Aynı tipte bir diğer örnek M1, Miletos, Heroon III buluntuları arasında da yer almaktadır (Pülz 1985, 102, Res. 3, No. 25). Bu tip İtalya'da MÖ II. yüzyıl ortalarından itibaren erken Augustus Dönemi'ne kadar görülür (Moevs 1973, 59). Miletos örneklerinin en yakın benzerleri Ephesos'tan (Ladstätter 2005, 235, 282 vd. K159-K162, Lev. 155) ve Priene'den (Fenn 2016, 136, Lev. 76, B120, B121) ele geçen parçalardır. Geç Augustus Dönemi tabakalarından gelen bu örneklerin analojisi için Ladtstätter ve Fenn'in İtalya üretimi farklı parçaları referans göstermiş olmaları, batıya özgü formların doğuda yeniden yorumlanmış olması nedeniyle, söz konusu örneklerin İtalya repertuvarından tam paralellerinin bulunamadığına işaret etmektedir (bk. Fenn 2016, 136 dn. 1374). Atina Agorası'ndan ele geçen benzer tipte 6 örnek Geç Cumhuriyet-Erken İmparatorluk Dönemi arasina tarihlenir (Hayes 2008, 97, No. 1505-1511).

Ağız kenarları daha yüksek olan No. 2, No. 3 ve M2, M. Moevs'in Form VII olarak gruplandırdığı içki kabı ile paralellik göstermektedir (Moevs 1973, 66, No. 69-78, Lev. 7, 59.). Bu tip Priene'de Erken İmparatorluk Dönemi'ne tarihlenen buluntu topluluklarından gelmektedir (Fenn 2016, 136). Aynı zamanda, Ephesos'ta Devlet Agorası'ndaki kuyuda A dolgu tabakasında ve Yamaç Ev'de MÖ I. yüzyilın ikinci yarısına tarihlenen buluntu topluluklarından da bilinmektedir (Meriç 2002, 72, 77, K360, Lev. 32; Ladstätter 2005, 235, 282, K163, Lev. 155). Sığ dipli ve çok ince cidarlı No.4, de yine Erken İmparatorluk Dönemi'ne
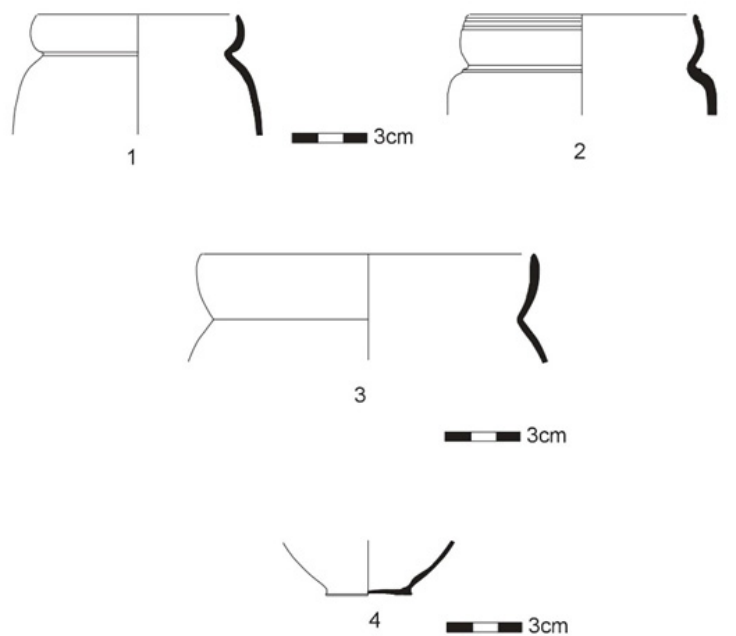

Fig. 6. Elips gövdeli içki kapları (Çizim: R. Şahin)

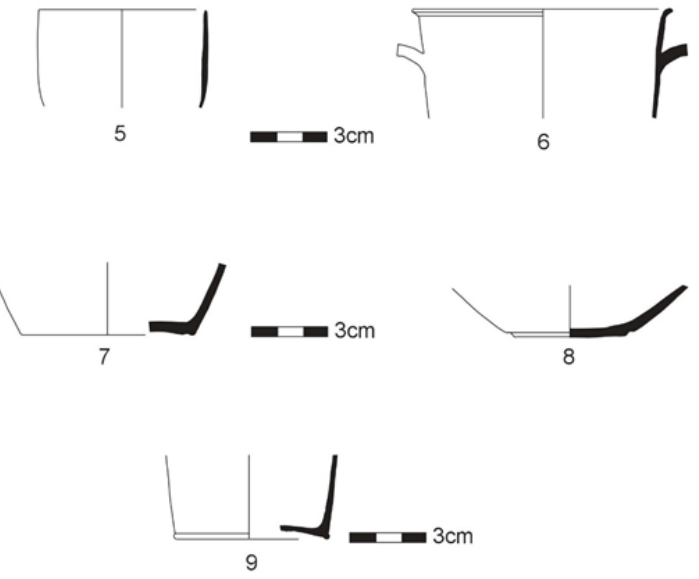

Fig. 7. Konik gövdeli içki kapları (Çizim: R. Şahin) tarihlenen, elips gövdeli içki kaplarında görülen bir dip profiline sahiptir.

Konik Gövdeli İçki Kapları (Fig. 7, No. 5-8)

No. 5 ağı-gövde arası düz bir profile sahiptir. Bu özellik konik gövdeli kaplar için belirleyicidir (Moevs Form XXX: Moevs 1973, No. 156, Lev. 14, 63; Ricci 1985, Lev. 88 No. 9). Hafifçe dişa 
çekik ağızlı, dikey kulplu No.6 da konik gövdeli içki kabı olarak sınıflandırılabilir (Moevs Form XII: Moevs 1973, 74, No. 96; Ricci 1985, 275, Lev. 95, No. 5). No. 7 ve No. 8 de aynı tipte örneklere ait dip parçalarıdır. Konik gövdeli içki kaplarının Atina Agorası (Hayes 2008, 99, Res. 46, No. 1510; No. 1537), Ephesos (Mitsopoulos-Leon 1991, Lev. 187, K19; Ladstätter 2005, Lev. 155, 210, No. K146-150; Ladstätter 2005, 235, 283 vd. Lev. 155, K157, 158) ve Priene'de (Fenn 2016, 137, Lev. 76, B131; a.e. 136, B126-128) ele geçen paralelleri Augustus Dönemi'ne tarihlenmektedir.

Diğer İçki Kapları (Fig. 7, No.9)

No. 9 düz silindirik bir gövdeye ve profilli bir dip kesimine sahiptir. Paralelleri İtalya repertuvarından bilinmektedir (Ettlinger 1990, Lev. 27, Form 29; ayrıca krş. Moevs 1973, Lev. 8, 60 (Form 12); Lev. 11, 61 (Form 23). Ephesos'ta MÖ I. yüzyıl başlarını tarihlenen buluntu topluluklarından ele geçmiştir. (Ladstätter 2005, Lev. 156, K174; Meriç 2002, 72, K358; Gassner 1996, No. 627). Aynı zamanda bu formun Ephesos'tan bilinen ESB grubundan örnekleri de yine bu tarih aralığına sınıflandırılmıştır (Mitsopoulos-Leon 1991, H205-207).

Kase Formunda Kaplar (Tablo 1, M3-M5)

Mevcut buluntular arasında kaseler, içki kaplarına kıyasla daha az yaygın bir kategoriyi oluşturmaktadır. Dışa çekik ağızlı kase parçası M3, Heroon III'ten ele geçmiştir ve gelmiş olduğu kontekst Erken İmparatorluk Dönemi'ne tarihlenmektedir (Pülz 1985, Res. 3, No.27). M3'ün Cosa'dan en yakın paraleli MÖ 70-30 arasına tarihlenir (Moevs Form XXXVIII: Moevs 1973,112, No. 198-199, Lev. 20, 66).

Miletos, Heroon I'de pithostan ele geçen bir diğer kâse M4, konveks profilli bir ağıza sahiptir (Pülz 1986, 22, Res. 3, No. 9). Ağız ile gövde arasındaki keskin geçiş, belirgin bir dirsek oluşturmaktadır. Kap gövdesi aşağ doğru belirgin biçimde daralmaktadır. Bu özellikler MS I. yüzyılın ilk yarısına tarihlenen yarım daire formundaki kâselerde görülür. (Moevs Form XXXVI: Moevs 1973, No. 180-194, Lev. 18, 19, 65, 66). Heroon I kâsesi ile karşılaştırma yapmaya olanak sağlayan bir örnek Ephesos'ta, Erken İmparatorluk Dönemi tabakalarından ele geçmiştir (Mitsopoulos-Leon 1991, 137, Lev. 192, K29-30).

M5, Heroon III'ten ele geçen bir kâse üzerinde parmak baskısı bezemesi yer almaktadır (Pülz 1987, 52 No. 30). Keramiğe cam etkisi veren parmak baskısı bezemeli kasenin tipolojik olarak Batı Akdeniz'den en yakın paralelleri MÖ I. yüzyılın ikinci ve üçüncü çeyreğine tarihlenir (Moevs Form XXXVII: Moevs 1973, 86, No. 132-133, Lev. 12, 62; a.e. Lev. 46, No. 434; Lev. 22, 217; Ricci, Tipo 1/86 ve 1/87: Ricci 1985, 83, No. 12, 13; ayrica form ile ilgili daha ayrıntılı bilgi ve Pergamon örnekleri için bk. Japp 1999, 305). E. Doksanaltı M5'i Knidos üretimi olarak sınıflandırmıştır (Doksanaltı 2006, 25, dn. 12). "Faltenbecher" olarak da adlandırılan bu kapların Knidos'ta en yoğun ele geçtikleri dönem MS I. yüzyılın ilk yarısıdır (Kögler 2010, 341-342, 344; Res.65, Lev. 63, Kn.411-423; Kögler 2005, 57 Res. 13.). Knossos'tan ele geçen bir diğer parmak baskılı Knidos üretimi kase ise Flaviuslar Dönemi'ne tarihlenen bir kontekstten gelmektedir (Sackett 1992, 165, Lev. 147, C1.82).

\section{Maşrapalar}

\section{Asker Kapları "Soldatenbecher" (Tablo 1, M6-M7)}

M6 ve M7, Heroon III’ten ele geçen iki kap paçasında ağızdan aşağı doğru hafifçe genişleyen gövde bir yiv ile iki kısma ayrılmıştır (Pülz 1987, 58, No. 54, 55). Aynı zamanda bu örneklerde hamur çok sert pişmiştir. İtalya'da MÖ II. yüzyıl başlarından itibaren üretildikleri bilinen Asker Kapları "Soldatenbecher" Heroon III örneklerine en yakın paraleli sunmaktadır (Moevs Form XVII, Moevs 1973, 77, 78, No. 110, Lev. 10, 61). Kaba yüzey işçiliği asker kaplarının ayırıcı özelliğidir (Hayes 2008, 98). Ephesos'ta Bazilika'nın Geç Augustus-Erken Tiberius Dönemi son 
inşa evresine tarihlenen buluntu topluluğundan ele geçen benzerlerini Mitsopoulos-Leon, "Beutelbecher" olarak isimlendirir (Mitsopoulos-Leon 1991,134; K25- K28; Lev. 189, 192). Atina Agorası'ndaki paralelleri geç Cumhuriyet-Erken İmparatorluk Dönemi'ne tarihlenmekte$\operatorname{dir}$ (Hayes 2008, 98, No. 1514-1520).

\section{“Boccalini a Collarino” Tipi Maşrapalar (Tablo 1, M8-M9)}

Heroon III'ten ele geçmiş olan ağız parçaları M8 ve M9 konveks profillidir (Pülz 1985, Res. 3, No. 28; Pülz 1987, 53, Res. 13, 37). Her iki örnekte de gövde aşağı doğru hafifçe açılmaktadır. M8 ve M9'un Cosa'dan ele geçen paralelleri MÖ I. yüzyılın üçüncü çeyreğine tarihlenmektedir (Moevs Form VII: Moevs 1973, No. 69-78, Lev. 7, 59; Moevs Form VIII: Moevs 1973, No. 86, Lev. 8, 60). "Boccalini a Collarino" tipi maşrapaların erken tipini temsil eden söz konusu örnekler MÖ I- MS I. yüzyıl boyunca yaygın biçimde kullanılmışlardır (krş. Robinson 1959, 30 vd. Lev. 5, G103, Lev.7, G119). Bu form Phokaia, Ephesos, Pergamon, Assos ve Troas gibi pek çok merkezden bilinmektedir (Phokaia: Özyiğit 1991, 99 vd. Res. 9a; Özyiğit 1990, 148, Res. 14; Ephesos: Meriç 2002, 82, K455,456, Lev. 39; Pergamon: Japp 1999, 319, No. 33, Res. 2, Lev. 27; Assos: Filges 1990, 86, No. 1,2; Troas: Heath \& Tekkök, 2017a; ayrıca İnegöl'den ele geçen bir örnek için bk. Çıtakoğlu \& Gülsefa 2017, 342, No. 7).

"Urnetta/Boccalino a Collarino" Tipi Maşrapalar (Tablo 1, M10-M11)

Daha az yaygın olan ikinci seri maşrapalar Lamboglia tarafindan "Urnetta/Boccalino a Collarino" tipi olarak adlandırılmaktadır (Lamboglia 1962, 285, No. 30, Res. 19:A; ayrıca Atina Agoras1 örnekleri için bk. Hayes 2008, 102, No. 1602-1608). Miletos' ta Heroon III'ten ele geçen M10 ve M11'de, dışa çekik ağız, gövdeye oranla kısa kalmaktadır (Pülz 1985, Res. 3,5, No. 29,47). Gövde aşağıya doğru genişleyen küresel formdadır. Ağızdan gövdeye geçişte yer alan kabartma bir bileziğe sahip olan bu örnekler M. Moevs'in, MÖ I. yüzyıla tarihlediği Form XIV ile karşılaştırılabilir (Moevs 1973, Lev. 9, No. 99). Bu örneklerin Ainos'ta MÖ I. yüzyıl sonlarına tarihlenen mezarlardan ele geçen paralellerini, S. Başaran Tip I olarak sınıflandırmaktadır (Başaran 2003, 72, Lev. 46, No. 1, 4). Ainos ve Troia'da çok sayıda ele geçmiş olması bu tipin Ege'nin kuzeydoğusunda üretilmiş olabileceğini düşündürmektedir (Hayes 2008, 102, dn. 67; Erzen \& Başaran 1988, 100, Res. 13; Erzen \& Başaran 1990, 208, Res. 11,14, 15; Başaran 1997, 497 , 512, Res. 20; Heath \& Tekkök, 2017a).

\section{MS II.-III. Yüzyıl İnce Cidarlı Kapları}

Huni Ağızlı “Boccalini a Collarino” Tipi Maşrapalar (Fig. 8, No.10-13; Tablo 1, M12-M14)

Hemen hemen eksiksiz olarak ele geçmiş olan No. 10'un ağzı dışa doğru hafifçe açılan huni formundadır. Ağızdan boyuna geçişte yer alan yiv, keskin bir dirsek oluşturmaktadır. Gövdenin alt kesimi şişkindir. Kap sarımsı ve pütürlü bir yüzeye sahiptir. Hayes, Miletos örneğinde olduğu gibi ağzı dışa doğru huni biçiminde açılan "Boccalini a Collarino" tipinin Doğu Ege 'ye özgü olduğunu bildirmektedir (Hayes 2008, 101, Res. 50, No. 1597-1600). No. 10'un formu ve kil özellikleri Phokaia üretimi olduğunu düşündürmektedir. En yakın paraleli Ö. Özyiğit tarafından MS III. yüzyıl başlarına tarihlenir. (Özyiğit 1992, 115, Res. 9b). Phokaia üretimi huni ağızlı maşrapalar Ephesos ve Didyma'da MS II. ve III. yüzyıla tarihlenen

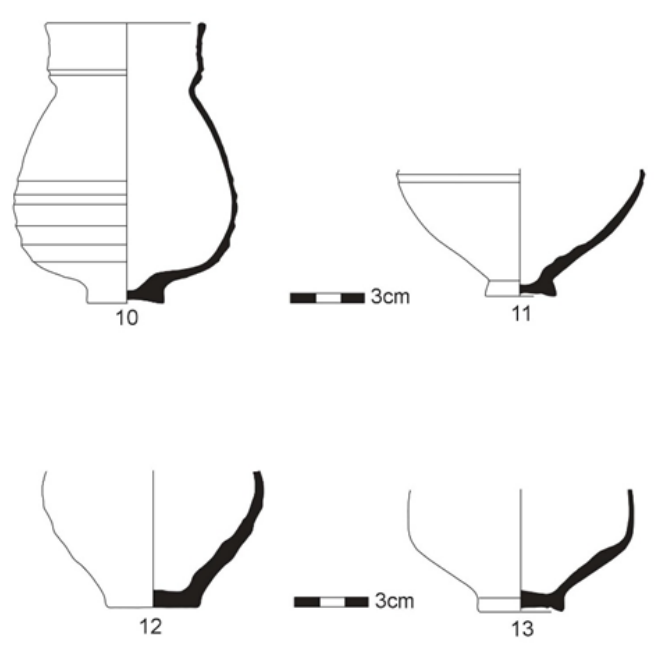

Fig. 8. Huni Ağızlı MS II.-III. Yüzyıl Maşrapaları (Çizim: R. Şahin) 
buluntu topluluklarında tespit edilmiştir (Ephesos: Ladstätter 2010, B-K 477, Lev. 226; 237; a.e. Kat. A-K 407-423; Ladstätter 2010, 266, Lev. 108/A-K 806; Ladstätter 2014, Lev. 192, K828; Ladstätter 2008, Lev. 293, K188, Didyma: Wintermeyer 2004, 92, Tip 2.3, 2.4, 2.5, 2.6, 2.8, 2.10, Res. 664-669, Menderes Magnesias1: Vapur 2011, 156,No. 38, Çizim 4).

Yine aynı tipte maşrapalara ait olması muhtemel gövde ve dip parçaları No.11 No.12 ve No.13 hamur içeriği ve yüzey işlenişi bakımından No.11'den ayrılmaktadırlar. Boccalino $e$ Collarino tipi maşrapaların MS II.-III. yüzyıl tipinin Miletos'tan bilinen diğer örneklerinden M12 ve M13, Heroon I'den (Pülz 1986, 23, Res. 4, No. 13 ve No.18); M14: ise Piskoposluk Saray1 yanındaki Peristylli Ev'in batısındaki bir buluntu topluluğundan ele geçmiştir (Niewöhner et al. 2015b, 235, Res. 83, No. 18).

\section{İnce Cidarlı Keramiklerin Üretim Merkezleri Sorunu}

\section{Miletos, İnce Cidarlı Keramiklerin Üretim Merkezleri}

Miletos'tan ele geçen ince cidarlı kapların formları, hamur ve astar özellikleri ince cidarlı kapların farklı üretim merkezlerinden geldiğini göstermektedir. Öte yandan mevcut buluntular arasında kesin olarak İtalya Üretimi olarak sınıflandırılabilecek özellikte bir örnek tespit edilememiştir. İnce keramik görünümlü, mat astarlı, orta kalınlıkta cidara sahip No. 1, 3, 7 ve 11 Meander Bölgesi' ne özgü ince mikalı katkılı bir kile sahiptir. Bu özellikteki hamur ve astar dokusuna sahip kaplar Priene (Fenn 2016, 147, Lev. 79, B168, B169) ve Ephesos'tan da (Meriç 2002, Lev. 38, 39, K443-450; K452-459) bilinmektedir. R. Meriç'in "Getunkte Ware" olarak sinıflandırdığ 1 bu örneklerin yerel atölyelerde üretilmiş olduğu düşünülmektedir (Meriç 2002, 70). Aynı zamanda, çok ince cidarlı, çok sert pişmiş ve ince elenmiş ve parlak astarlı No. 2,6 ve 7'nin de bölge atölyelerinden gelmiş olması muhtemeldir.

No. 10 huni ağızlı maşrapanın ise formu yanı sıra, açık gri, pütürlü dış yüzeyi, kireç ve taşçık katkılı hamuru nedeniyle Phokaia üretimi olduğu düşünülmektedir (Phokaia üretimi örneklerin hamur tanımı için bk. Hayes 2008, 101). Aynı tipteki No. 12, No. 13 ve M12, M13, (Pülz 1986, 23, Res. 4, 5, No. 13, 18); Miletos'tan ele geçen masa servislerinde de görülen çok sert pişmiş, pembemsi ya da grimsi renkte hamura sahiptir. E. Doksanaltı tarafından Knidos üretimi olduğu bildirilen M5, parmak baskı1ı kase Knidos üretimi örneklere özgü ince elenmiş, kahverengi kırmızımsı (Munsell: 7.5 YR 8/6), kireç katkılı hamur dokusuna sahiptir (krş. Pülz 1987, 40; Doksanaltı 2006, 25, dn. 12. a.e. 25, 26). Menderes Havzası dışından bölgeye gelmiş olmas1 muhtemel diğer iki örnek ise M10 ve M11, Kuzey Ege'ye özgü, bilezikli Urnetta/ Boccalino a Collarino Tipi Maşrapalardır. Mevcut buluntular, ince cidarlı kapların Miletos'a büyük ölçüde Menderes Havzası'nda ve Batı Anadolu'da üretim yapan diğer merkezlerden geldiğine işaret etmektedir.

\section{Batı Akdeniz'den İthal İnce Cidarlı Keramiklerin Ege'de Dolaşımı}

Atina Agorası'ndan ele geçen ince cidarlı kapların büyük kısmı İtalya' nın kuzeyinde üretilmiş olan örneklerden oluşmaktadır (Hayes 2008, 95). Az sayıda, düz bir yüzeye sahip ince cidarlı kap ise Doğu Ege üretimidir (Hayes 2008, 96). Korinthos'ta mevcut buluntuların önemli bir bölümünü Batı Akdeniz üretimi örnekler oluşturmaktadır (Hayes 1973, 460,461, Lev. 89, No. 179-193). Sackett Knossos'tan ele geçen 345 parça ince cidarlı kabın \%54'ünün Kuzey İtalya üretimi gri hamurlu örneklerden oluşturduğunu bildirir (Sackett 1992, 165-166).

Paphos'un ince cidarlı kap buluntuları arasında İtalya'nın yanı sıra Doğu Akdeniz'den Kıbrıs, Knidos ve Misır gibi farklı üretim merkezlerinden örnekler de dikkate değer miktarda temsil edilmiştir (Hayes 1991, 59-63).

Anadolu'nun batı kıyılarında ise Ephesos (Meriç 2002, K405, K442a), Troia (Heath-Tekkök, 2017a), Pergamon (Pirson vd. 2015, 152) ve Knidos (Doksanaltı 2006, 24, dn. 9; Kögler 2004, 
Res. 8, Lev. 11; a.e. 88, Res. 12- 13) gibi merkezlerde İtalya üretimi ince cidarlı kaplar başlangıçtan itibaren sınırlı sayıda talep görmüştür. Bununla birlikte MS I. yüzyıl sonlarına doğru Doğu Ege üretimlerinin, Küçük Asya'nın batısında önemli bir yere sahip olduğu görülmektedir (Kögler 2010, 340, dn. 1771, ayrıca bk. Fenn 2016, 146). Öte yandan, Halikarnassos' tan ele geçen buluntuların dikkate değer bir bölümünün batı Akdeniz üretimi ince cidarlı kapların oluşturuyor olması Küçük Asya'nın batısındaki diğer pek çok merkezle karşılaştırıldığında istisnai bir durumdur (Hansen 2003, 197).

\section{Batı Anadolu'da İnce Cidarlı Keramik Üreten Atölyeler}

\section{Ionia ve Güney Batı Anadolu}

Ephesos'ta Devlet Agorasında A, B ve D dolgularından (Meriç 2002, 70), yine Devlet Agoras1'ndaki Bazilika'dan (Mitsopoulos-Leon 1991, 131) ve Yamaç Ev I'den (Outschar 1996, 58) ele geçen buluntuların büyük bölümü yerel üretim olarak sınıflandırılmıştır. Güney Ionia'nın diğer kentlerinde de üretim olduğunu gösteren bulgular mevcuttur. N. Fenn, virgül bezemeli kapların (Acobecher) bezeme bakımından ünik örneklerini referans göstererek Priene'de ince cidarlı keramik üreten atölyelerin var olduğunu bildirmektedir (Fenn 2016, 147). Öte yandan Priene'de, Ephesos üretimi örneklerin olduğu tahmin edilmesine rağmen, iki grup arasında makroskopik bir ayrım yapmak hemen hemen imkânsız olduğundan Ephesos kökenli kapların kapsamı mevcut durumda belirsizdir (Fenn 2016, 147).

U. Wintermeyer Miletos ve Didyma'ya (aynı zamanda Ephesos, Samos ve Latmos Herakleia'ya da) kaba keramik üreten ortak bir atölye olduğunu ve bu atölyenin ürünleri arasında ince cidarlı kaplar da bulunduğunu bildirmektedir (Wintermeyer 2004, 5, dn. 11). Yine aynı atölyenin ürünü olan sert pişmiş açık ya da koyu gri hamurlu keramikler ise Pergamon, Atina ve Demetrias başta olmak üzere pek çok merkezde temsil edilmektedir (Wintermeyer 2004, 5, dn. 11).

Küçük Asya'nın batı kıyılarında bölgeler arası pazarlarda ürünleri talep gören ince cidarlı keramik atölyelerinin var olduğu son yıllarda yapılan çalışmalarla kesinlik kazanmıştır. Parmak baskı11, barbotin ve çentik (kerbdekor) bezemeli gibi farklı gruplardan oluşan bir repertuvara sahip olan Knidos üretimi ince cidarlı kaplar Augustus Dönemi'nden itibaren- MS. 75 dolaylarına kadar üretilmişlerdir (Kögler 2010, 341). Knidos'ta ince cidarlı kap repertuvarının hemen hemen tamamına yakını kendi üretimlerinden oluşur (Kögler 2000a, 70 vd; Kögler 2004, 85-88; Kögler 2010, 343-344). Knidos üretimi parmak baskılı kaseler Priene ve Didyma'nın yanı sıra, yukarıda da değinildiği Miletos'ta da temsil edilmiştir (Fenn 2008, 249; Kögler 2010, 59; Wintermeyer 2004, 124 Typ Be 1.5 Res. 1169; Pülz 1987, 41, No 24- 27, 30, Res. 11- 12). Knidos üretimi ince cidarlı keramiklerin Adriyatik kıyıları, Yunanistan, Kuzey Afrika kıyıları; Kıbrıs ve Girit başta olmak üzere Ege ve Akdeniz'de pek çok merkezde talep gördüğü bilinmektedir (Kögler 2010, 58,59, 343, 344; Doksanaltı 2006, 25'te dn. 12'de buluntu yerlerini ayrıntılı olarak saymaktadır: Berenice: Kenrick 1985, 313, B458, Res. 58; Kolones PaphosKibris: Rosser 1985, 95, No 48, Res. H7; Knossos-Girit: Sackett 1992, lev. 147: No C1.78, 8182; Lev. 157, N1.20- 21; Lev. 154: C2. 66; Lev. 175: D4. 16; Korinthos: Hayes 1973, 463, 65 , No 199, 224, Lev. 80, 90; Adriyatik Kiyıları: Brusić 1999, 30, 117, No 396, Res. 57)

"Boccalini a Collarino" Tipi maşrapalar ise MS I. yüzyıldan itibaren Phokaia'da pişirme kab1 atölyelerinde üretilmişlerdir (Özyiğit 1991, 138, Kögler 2010, 340, Fenn 2016, 146). Özellikle MS II. ve III. yüzyılda üretilen huni ağızlı şişkin gövdeli Phokaia maşrapaları Girit'i de içine alan tüm Ege ve Adriatik kıyllarında yoğun biçimde talep görmüştür (Ionia' da ele geçtiği buluntu yerleri yukarıda, ilgili bölümde özetlenmiştir; Ege ve Akdeniz'de ele geçtiği buluntu yerlerinin ayrıntılı listesi için bk. Hayes 2008, 102, dn. 59-64). No.11, Miletos'ta da bu tipteki maşrapaların talep gördüğüne işaret etmektedir. 


\section{Kuzey Batı Anadolu}

Pergamon'da MÖ I. yüzyıl sonu ile MS. I. yüzyıl başlarında ve Milat yıllarında en yoğun miktarda üretildiği bilinen beyaz hamurlu dış yüzeyi beyaz perdahlı ince cidarlı "Eierschale" ve siyah parlak firnisli kaplar dış pazarlarda ilgi gören ince cidarlı keramik gruplarıdır (Japp 1999, 303,304 ). Pergamon'a özgü X ve Y tipi maşrapalar da kentte farklı buluntu gruplarında en çok temsil edilen ince cidarlı kaplardır (Japp 1999, 304- 307 Ayrica bk. Loeschcke 1912, 392, Res, 10, 1; a.e. dn. 26). Priene'den ele geçen örnekler arasında- kil analizleri ile kesinliği onaylanmış olan- Pergamon kökenli ince cidarlı kaplar bulunmaktadır (Fenn 2008, 249).

Kuzey Ege'de Geç Hellenistik ve Erken İmparatorluk Dönemi'nde (MÖ II.-I. yüzyıl-MS 50) üretim olduğu Hayes tarafından ileri sürülmüştür. Hayes, Troia ve Mytilini' de çokça ele geçen; öte yandan Ephesos'ta bilinmeyen konik gövdeli içki kaplarının ve kâselerin bazı tiplerinin üretim yerinin Kuzey Ege'de aranması gerektiği üzerinde durmaktadır (Hayes 2005, 21). Assos’taki üretim faaliyetleri ile ilgili bilgiler ise oldukça yüzeysel kalmaktadır. A.Filges Assos'tan ele geçen buluntuları yerel olarak nitelendirmiştir (Filges 1990, 79).

Hayes'in "Urnetta-Boccalino a Collarino" tipi olarak adlandırdığı ve S. Başaran'ın tipolojisinde Ainos Tip I'e denk gelen, tek kulplu maşrapaların MÖ I. yüzyıl sonlarına tarihlenen erken tiplerinin muhtemel üretim yeri Khersonessos (Hayes 1996, 10), Ainos ya da genel olarak Trakya kıyılarıdır (Hayes 2005, 21; Başaran 2003, 72). Öte yandan Tip 1, MS I. yüzy1l ortalarından III. yüzyıla kadar Illion'da da yoğun talep görmüştür (Heath-Tekkök, 2017b). Geç dönem örneklerinin üretim yeri için Troia da önerilmiştir (Hayes 2005, 21). Kuzey Ege Tipi (Başaran Tip I) Miletos'tan ele geçen buluntular arasında da bu tip yer almaktadır (M10-11).

\section{Değerlendirme ve Sonuçlar}

Miletos'tan ele geçen ince cidarlı keramikler oldukça sınırlı bir kap repertuvarı sunmaktadır. Mevcut buluntular arasında Erken İmparatorluk Dönemi'ne tarihlenen ince cidarlı kaplar belirgin bir çoğunluktadır (Fig. 5). Erken İmparatorluk Dönemi'nde, elips ve konik gövdeli içki kapları en çok temsil edilen grubu oluşturmaktadır. MS II.-III. yüzyıla tarihlenen örnekler huni ağızlı maşrapalardan oluşmaktadır.

Elips ve konik gövdeli içki kapları Miletos'ta Erken İmparatorluk Dönemi'nde en çok talep gören örneklerdir. Bouleuterionun batısındaki WB59 açmasında ve Güney Hamamlar 'da Geç Hellenistik- Erken imparatorluk dönemi buluntularının ağırlıkta olduğu kontekstlerde ele geçmiştir. "Boccalini a Collarino" Tipi maşrapanın MS II.-III. yüzyıla tarihlenen huni ağızlı, şişkin gövdeli örneklerinin ise Heroon I- Pithos ve Piskoposluk Sarayı'nda, Orta İmparatorluk Dönemi buluntu topluluklarından ele geçmiş olduğu görülür.

Erken İmparatorluk Dönemi’ ne tarihlenen ince cidarlı kapların önemli bir bölümü Meander Deltası kil ve astar özelliği göstermektedir. Bunun yanı sıra buluntular arasında Knidos üretimi, parmak baskılı bir kase de yer almaktadır. MS II.-III. yüzyıla tarihlenen huni ağızlı maşrapa örnekleri arasında Phokaia üretimi olduğu anlaşılan bir örnek tespit edilmiştir. Öte yandan Heroon III'ten ele geçen Kuzey Ege'ye özgü "Urnetta a Collarino" Tipi maşrapa Kuzey Ege'den ithal üretimi olabilir.

İtalya üretimi ince cidarlı kapların Miletos'ta ilgi görmediği anlaşılmaktadır. Mevcut repertuvar Ionia kentlerinin pek çoğu gibi, Miletos'un da ağırlıklı olarak Doğu Ege atölyelerinden gelen ince cidarlı kaplara yöneldiğine işaret etmektedir. Kentin hemen yakınlarındaki merkezlerden Ephesos ve Priene'de üretim olduğuna dair bulgular mevcuttur. Miletos üretimi örneklerin bu merkezlerden gelen buluntular ile birbirinden makroskopik gözlemlerle ayırt edilebilmesinin zor oluşu göz önünde bulundurularak, yerel atölyelerde üretildiği düşünülen örneklerin daha genel bir ifade ile Meander bölgesi üretimi olarak adlandırılmasının daha uygun olacağı 
düşünülmektedir. Aynı zamanda Miletos'ta Pergamon'un X ve Y tipi maşrapaları ya da Priene'nin virgül bezemeli kaseleri (acobecher) gibi Miletos'a özgü karakteristik bir tipin tespit edilememiş olması da kentte üretim olup olmadığı konusundaki soruların yanıtsız kalmasına neden olmaktadir.

\section{Mali Destek Bildirimi}

Bu çalışma Uludağ Üniversitesi BAP birimi tarafindan finanse edilen, "KUAP (F) 2015/16" numaralı ve "Milet Antik Kenti Konut Yapılarında Ele Geçen Geç Hellenistik Dönem ve İmparatorluk Dönemi Keramikleri" başlıklı proje kapsamında gerçekleştirilmiştir.

This article is accomplished in frame of the project "KUAP (F) 2015/16: Milet Antik Kenti Konut Yapılarında Ele Geçen Geç Hellenistik Dönem ve Imparatorluk Dönemi Keramikleri", which is supported by BAP (Department of Scientific Research Projects) at Uludag University.

\section{Elips Gövdeli İçki Kapları}

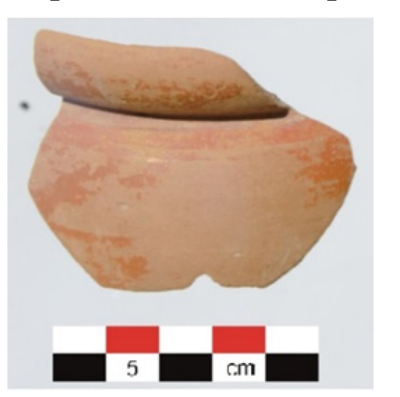

\section{KATALOG}

\section{No. 1}

Tanım: Ağız ve gövde parçası. Hamur: 5 YR 6/6 Astar: 5 YR 6/6 Ölçüler: Ağız çap: $8,4 \mathrm{~cm}$; yüks. $4,9 \mathrm{~cm}$

Buluntu Yeri: WB59O

Analoji: Moevs 1973, No. 37, Form IV, Pls. 4, 57, p. 59; Ricci 1985, Lev. 79, No. 5; Hayes 2008, 97, No. 1505-1511; Ladstätter 2005, 235, 282 f. K159-K162, Taf. 155, Fenn 2016, Lev. 76, B120-122; a.e. Lev. 68 B40.

Tarih: MÖ I. yüzyıl son çeyreği- MS I. yüzyıl ilk çeyreği

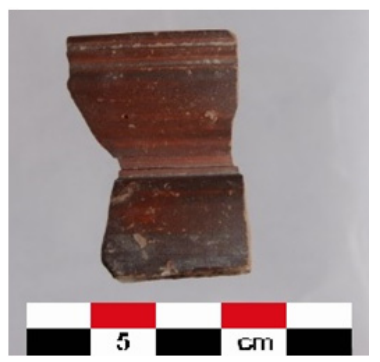

No. 2

Tanım: Ağız ve gövde parçası. Kil: 7.5 YR 6/6 Astar: içte kızıl kahve; dışta kızıl kahve-kahve. Ağız çap: 9cm; yüks. 3,3 cm.

Buluntu Yeri: WB59063

Analoji: Moevs 1973, 67 (Moevs FORM VII); Fenn 2016, 136, Pl. 76, B120-122, a.e. P1. 79 B169

Tarih: MÖ I. yüzyıl son çeyreği- MS I. yüzyıl ilk çeyreği

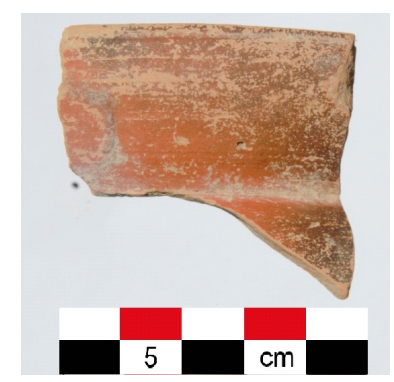

No. 3

Tanım: Ağız ve gövde parçası. Kil: 7.5 YR 6/6 Astar: 2.5 YR 5/6 yüzeyde yer yer koyu pişmiş. Ağız çap: $14 \mathrm{~cm}$; yüks. $4,5 \mathrm{~cm}$ Buluntu Yeri:WB59O

Analoji: Japp 1999, 317, no. 33; Fenn 2016, Pl. 76, B129; Ladstätter 2014, Pl. 192, K826; Hayes 2008, Fig. 48, 1550,1551.

Tarih: MÖ I. yüzyıl son çeyreği- MS I. yüzyıl ilk çeyreği 


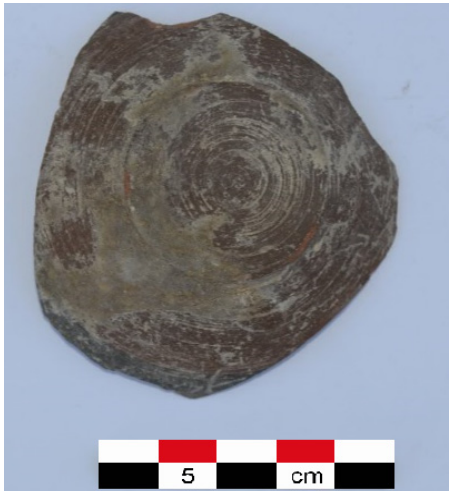

\section{Konik Gövdeli İçki Kapları}
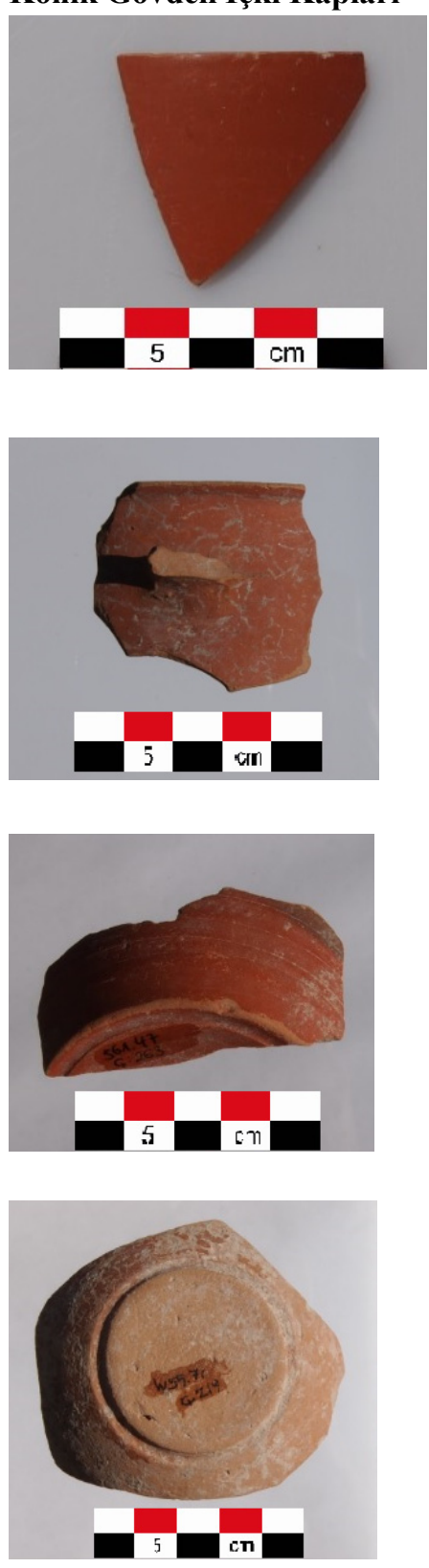

No. 4

Tanım: Dip parçası. Kil: 2.5YR 5/8 Astar: - Dip çapı: 3,5 cm; yüks. 2, $2 \mathrm{~cm}$

Buluntu Yeri: WB59035. 5

Analoji: Moevs 1973, Form VII, Pl. 7, No. 70,-72; Hayes 1985, Lev. 94 (Tipo 2/417), Ladstaetter 2008, Taf. 283, K42, K44; Taf. 293, K191.

Tarih: Augustus Dönemi

No. 5

Tanım: Ağıı ve gövde parçası, Kil: 2.5 YR 5/8 Astar: 2.5 YR 5/8 Ağız çap: $8,4 \mathrm{~cm}$; yüks. $3,7 \mathrm{~cm}$

Buluntu Yeri: WB59O56

Analoji: Moevs 1973,No. 156, Pls, 14, 63; FORM XXX; Moevs 173, Lev. 16, No. 169, 170; Hayes 2008, 99, Res. 46, No. 1510; Ricci 1985, Lev. 88 No. 9; Mitsopoulos-Leon 1991, Lev. 187, K19; Ladstätter 2005, Lev. 155, 210, K146-150; Fenn 2016, 137, Lev. 76, B131.

Tarih: Augustus Dönemi

No. 6

Tanım: Ağız, gövde ve kulp başı parçası. Kil: 5YR 6/6 Astar: 10R6/8 mat Ölçüler: Ağız çap: $10 \mathrm{~cm}$; yüks. 4, 2 cm

Buluntu Yeri: S61 21/23

Analoji: Moevs 1973, 74 Kat. No. 96 (Form XII); Ricci 1985, Lev. 95, No. 5; Hayes 2008, 99, No. 1537; Fenn 2016, 136, B126-128; Ladstätter 2005, 235, 283 vd. Lev. 155, K157, 158

Tarih: Augustus Dönemi

No. 7

Tanım: Dip parçası. Kil: 5YR 5/8 Astar: içte kahverengi mat; dışta kırmızı ve hafif sabunumsu Ölçüler: dip çap: $6,4 \mathrm{~cm}$; yüks. $2.8 \mathrm{~cm}$

Buluntu Yeri: S61.47

Analoji: Bk. No.5,6

Tarih: MÖ I. yüzyılın ikinci yarısı - Tiberius Dönemi

No. 8

Tanım: Dip parçası. Kil: 5YR 6/6 Astar: 5YR 6/6 Dip çapı : 4 cm; yüks. $2 \mathrm{~cm}$

Buluntu Yeri: WB59/71

Analoji: Bk. No.5,6

Tarih: MÖ I. yüzyılın ikinci yarısı - Tiberius Dönemi 


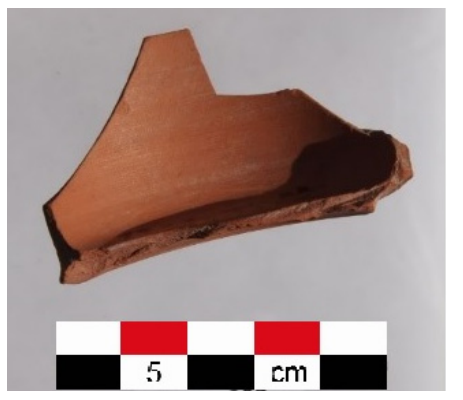

No. 9

Tanım: Tanım: Dip parçası. Kil: 2.5YR 5/8 Astar: 2.5YR 6/6 Dip çapı: $3 \mathrm{~cm}$; yüks. $3,2 \mathrm{~cm}$

Buluntu Yeri:WB59O

Analoji: Ladstätter 2005, Lev. 156, K174; Meriç 2002, 72, K358; Gassner 1996, No. 627; Japp 1999, Res. 3, No. 75; Mitsopoulos-Leon 1991, H205-207.

Tarih: MS 1. yüzyıl başları

\section{“Boccalini a Collarino” Tipi Maşrapa (MS II./III. Yüzyıl Örnekleri)}

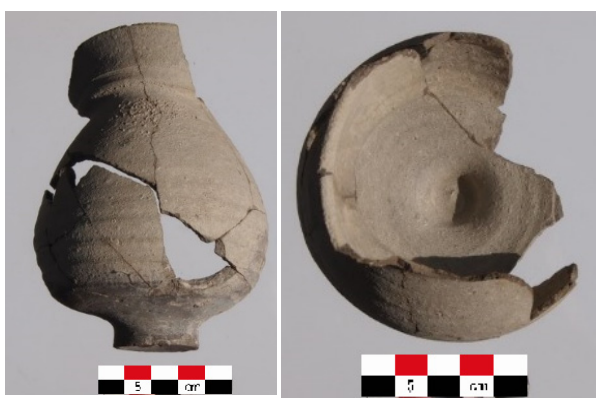

No. 10

Tanım: Gövdedeki eksik parçalar dışında tüme yakın. Kil: 7.5YR 5/1, çok sert pişmiş, mika, taşçık katkıları belirgin. Astar: - Ölçüler: Ağız çap: 7,5 cm; dip: $3 \mathrm{~cm}$; yüks. $11,1 \mathrm{~cm}$ Buluntu Yeri: S61/81

Analoji: Özyiğit 1992, 115, Resim 9b; Ladstätter 2014, Lev. 192, K828; Hayes 2008, Res. 50, No. 1600; Ladstätter 2008, Lev. 293, K188; Ricci 1985, Lev, 85, No. 7; Ladstätter 2010, Kat. A-K 407-423.

Tarih: MS II.-III. yüzyıl

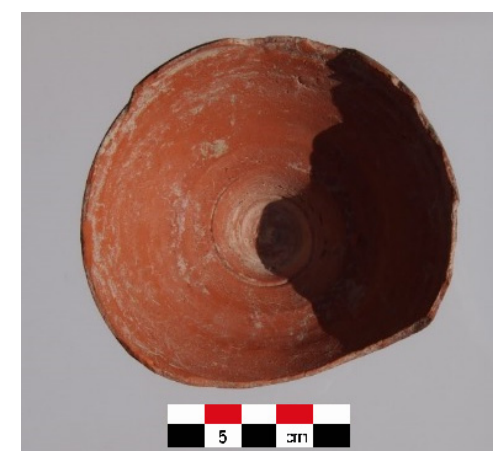

No. 11

Tanım: Dip parçası. Kil: 2.5YR 5/8, çok sert pişmiş, katkıları bol ve belirgin Astar: -dışta grimsi içte kırmızımsı pişmiş Dip çapı: $3 \mathrm{~cm}$; yüks. $4,9 \mathrm{~cm}$

Buluntu Yeri: S61/56

Analoji: Bk. No. 10

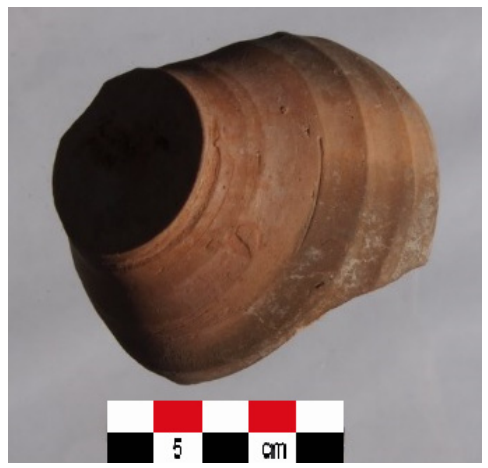

No. 12

Tanım: Dip parçası. Kil: 5YR 6/6, çekirdek açık gri pişmiş. Sert pişmiş, katkıları belirgin, hava deliği ve taşçık. Astar: - Dip çapı: 3,8 cm; yüks. 5,4 cm

Buluntu Yeri: S61/72

Analoji: Bk. No. 10 


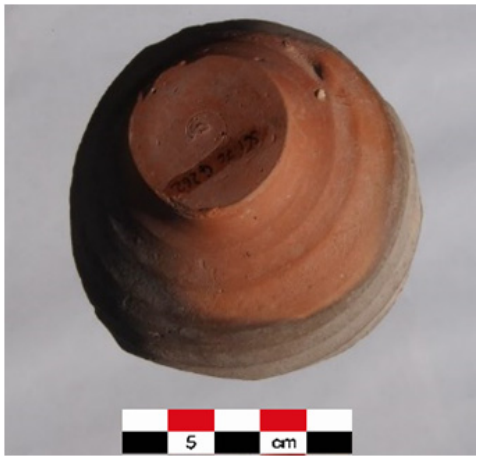

No. 13

Tanım: Dip parçası. Kil: 2.5YR 6/8, çekirdek açık gri pişmiş. gri topak şeklinde katkı, hava kabarcığı ve taşçık. Astar:dış yüzey yer yer siyah pişmiş, - Dip çapı: $3,4 \mathrm{~cm}$; yüks. $4,8 \mathrm{~cm}$

Buluntu Yeri: S61/76

Analoji: Bk. No. 10

YAYINLANMIŞ PARÇALAR

Erken İmparatorluk Dönemi İnce Cidarlı Kapları

İçki Kabı

Elips Gövdeli İçki Kabı

M1: Pülz 1985, 102, Res. 3, No. 25

Buluntu Yeri: Heroon III- NVIII

Analoji: Moevs 1973, Form IV

M2: Niewöhner vd. 2015a 227, Res. 80, No. 5

Buluntu Yeri: Güney Hamamlar, Kaldarium-

Hypokaust

Analoji: Moevs 1973, Form VII

Kaseler

M3:Pülz 1985, Res. 3, No. 27

Buluntu Yeri: Heroon III-NVIII

Analoji: Moevs 1973, Form XXXVIII

M4:Pülz 1986, 22, Res.. 3, No. 9

Buluntu Yeri: Heroon I- Pithos

Analoji: Moevs 1973, Form XXXVI

M5:Pülz 1987, 52, Res. 12, No. 30

Buluntu Yeri: Heroon III- S/T VI/VII

Analoji: Moevs 1973, Form XXXVII

Maşrapalar

Asker Kapları "Soldatenbecher"

M6: Pülz 1987, 58, Res. 18, No. 54

Buluntu Yeri: Heroon III- S/T VI/VII

Analoji: Moevs 1973, Form XVII

M7:Pülz 1987, 58, Res. 18, No. 55

Buluntu Yeri: Heroon III- S/T VI/VII

Analoji: Moevs 1973, Form XVII

“Boccalini a Collarino” Tipi Mașrapalar

M8: Pülz 1985, Res. 3, No. 28

Buluntu Yeri: Heroon III- S/T VI/VII

Analoji: Moevs 1973, Form VII; Form VIII

M9:Pülz 1987, 53, Res. 13, 37

Buluntu Yeri: Heroon III- S/T VI/VII

Analoji: Moevs 1973, Form VII; Form VIII

“Urnetta/Boccalino a Collarino" Tipi Maşrapa

M10:Pülz 1985, Res. 3, No. 29

Buluntu Yeri: Heroon III- U VIII-X VIII

(Kalkgrube)

Analoji: Moevs 1973, Form XIV

M11:Pülz 1985, 104, Res. 5, No. 47

Buluntu Yeri: Heroon III- U VIII-X VIII

(Kalkgrube)

Analoji: Moevs 1973, Form XIV

MS II./III. yüzyıl İnce Cidarlı Kapları

Huni Ağızlı “Boccalini a Collarino” Tipi

M12:Pülz 1986, 23, Res. 4, No. 13

Buluntu Yeri: Heroon I - Pithos

Analoji: Özyiğit 1992, 115, Res. 9b

M13:Pülz 1986, 23, Res. 5, No. 18

Buluntu Yeri: Heroon I - Pithos

Analoji: Özyiğit 1992, 115, Res. 9b
M14:Niewöhner vd. 2015b, 235, Res. 83, No. 18

Buluntu Yeri: Piskoposluk Sarayı

Analoji: Özyiğit 1992, 115, Res. 9b 


\section{KAYNAKÇA}

Başaran S. (1997). “Enez (Ainos) 1995 Yılı Kazı ve Onarım Çalışmaları”. KST XVIII (1996) 489-513.

Başaran S. (2003). “Ainos'un Geç Hellenistik-Erken Roma Dönemi Seramik Buluntuları”. Ed. A. Reynal, Les céramiques en Anatolie aux époques hellénistique et romaine: Actes de la table ronde d'Istanbul, 22-24 mai 1996. Varia Anatolica XV (2003) 71-77. Paris.

Brusić Z. (1999). Hellenistic and Roman Relief Pottery in Liburnia (North-East Adriatic, Croatia). Oxford 1999.

Carandini A. (1977) "La Ceramica A Pareti Sottili.” L'instrumentum Domesticum di Ercolano e Pompei”. Ed. A. Carandini. La Ceramica A Pareti Sotili di Pompei e del Museo Nazionale di Napoli (1977) 2531. Roma.

Çıtakoğlu H. \& Gülsefa G. (2017). “İnegöl Kent Müzesi’nde Sergilenen Hellenistik, Roma ve Bizans Dönemi Seramikleri”. Eds. D. Yavaş \& S. Sevim, Uluslararası İnegöl Tarihi ve Kültürü Sempozyuтu 14-16 Ekim 2016. 1. Cilt (2017) 323-348. İstanbul.

Doksanaltı E. (2006). “Kap Krio Buluntuları Işığında Knidos 'İnce Cidarlı’ Seramiği”. IDOL 8/31 (2006) 24-31.

Elaigne S. (2000). "Fine Ware from Late Hellenistic (Second Half of the First Century B.C.), Augustan and Tiberian Deposits of the French Excavations in Alexandria (Egypt)". ReiCretActa 36 (2000) 19-30.

Erzen A. \& Başaran S. (1988). “1988 yılı Enez Kazısı Çalışmaları”. Höyük 1 (1988) 97-101.

Erzen A. \& Başaran S. (1990). “1988 Yılı Enez Kazısı Çalışmaları”. KST XI (1989) 107-124.

Ettlinger, E. et al. (1990). Conspectus Formarum Terrae Sigillatae Italico Modo Confeciae, Bonn 1990

Fenn N. (2008) "Thin-Walled Pottery from an Early Imperial Complex at Priene/Ionia". ReiCretActa 40 (2006(2008)) 249-254.

Fenn N. (2016). Späthellenistische und Frühkaiserzeitliche Keramik aus Priene: Untersuchungen zu Herkunft und Produktion. Wiesbaden 2016.

Filges A. (1990). "Hellenistische und kaiserzeitliche unverzierte dünnwandige Keramik". Eds. Ü. Serdaroğlu, R. Stupperich \& E. Schwertheim, Ausgrabungen in Assos (1990) 79-89. Bonn.

Gassner V. (1997). Das Südtor der Tetragonos-Agora: Keramik und Kleinfunde. Wien 1997.

Hansen S. L. (2003). The Roman and Late Roman Fine Wares from the Danisch Excavations of a Late Roman Villa at Halicarnassos. Ed. A. Reynal, Les céramiques en Anatolie aux époques hellénistique et romaine: Actes de la table ronde d'Istanbul, 22-24 mai 1996. Varia Anatolica XV (2003) 197-201. Paris.

Hayes J. W. (1963/1964). "Notes on Roman Pottery in Greece and the Aegean". ReiCretActa 5/6 (1963/1964) 31-36.

Hayes J. W. (1973). "Roman Pottery from the South Stoa at Corinth”. Hesperia 42 (1973) 416-70.

Hayes J. W. (1976). Roman Pottery in the Royal Ontario Museum. Toronto 1976.

Hayes J. W. (1991). The Hellenstic and Roman Pottery. Paphos 3. Nicosia 1991.

Hayes J. W. (1995). “An Early Roman Well Group from the Troia Excavations, 1992”. StTroica 5 (1995) 185-196.

Hayes J. W. (1996). "Recent Work on Roman Imported Pottery from the Athenian Agora and the Isthmian Sanctuary”. Eds. M. Herfort-Koch et al., Hellenistische und Kaiserzeitliche Keramik des Östlichen Mittelmeergebietes (1996) 7-17. Frankfurt am Main.

Hayes J. W. (2005). "Late Hellenistic and Roman Pottery in the Eastern Mediterranean- an Overview of Recent Developmentes". Eds. M. B. Briese \& L. E. Vaag, The Relations in the Eastern Mediterranean from the Late Hellenistic Period to Late Antiquity. Odense. (2005) 11-26.

Hayes J. W. (2008). Roman Pottery Fine-Ware Imports. Princeton 2008.

Heath S. \& Tekkök B. (Eds.) (2017a). "Early Roman Thin-walled Wares". Greek, Roman and Byzantine Pottery at Ilion (Troia). Source: http://classics.uc.edu/troy/grbpottery/html/r-tw-early.html.

Heath S. \& Tekkök B. (Eds.) (2017b). "Thin Walled Cups/Jugs of the Roman Period" Greek, Roman and Byzantine Pottery at Ilion (Troia). Source: $<$ http://classics.uc.edu/troy/grbpottery/html/r-tw-cupsjugs.html $>$.

Hellström P. (1971). Labraunda Pottery of Classical and Later Date Terrakotta Lamps and Glas. Lund 1971.

Japp S. (1999). “Frührömische dünnwandige Hartware aus Pergamon”. IstMitt 49 (1999) 301-331.

Japp S. (2003). "Sigillata und dünnwandige Hartware aus Pergamon- Bemerkungen zu westlichen Importen und stilistischer Einflußnahme”. ReiCretActa 38 (2003) 243-246.

Kenrick P. M. (1985). The Fine Pottery. Excavations at Sidi Khrebish Benghazi (Berenice) 3,1. LibAnt Suppl 5. Tripoli 1985.

Kleiner G. \& Müller-Wiener W. (1972). “Die Grabung in Milet im Herbst 1959”. IstMitt 22 (1972) 45-92.

Kleiner G. (1961). "Bericht über die Grabung in Milet im Herbst 1961”. TAD 11/2 (1961) 46-48. 
Kleiner G. (1968). "Die Grabung in Milet im Herbst 1968”. TAD 17/1 (1968) 75-78.

Kossatz A. U. (1990) Die megarischen Becher. Milet I. Berlin 1990.

Kögler P. (2000). "Frühkaiserzeitliche Feinkeramik aus Knidos. Die Füllung einer Zisterne in der sogenannten Blocked Stoa". ReiCretActa 36 (2000) 69-74.

Kögler P. (2004). "Italische Einflüsse in der knidischen Keramik der frühen Kaiserzeit". Eds. Poblome et al., Early Italian Sigillata. The Chronological Framework and Trade Patterns. Proceedings of the First International ROCT-Congress, Leuven, May 7 and 8, 1999 (2004) 81-93. Leuven.

Kögler P. (2005). "Import, Export, Imitation. Trade and the Economic Power of Late Hellenistic and Early Imperial Knidos According to the Fine Pottery". Eds. M. B. Briese \& L. E. Vaag, The Relations in the Eastern Mediterrannean from the Late Hellenistic Period to Late Antiquity (2005) 50-62. Odense.

Kögler P. (2010). Feinkeramik aus Knidos: vom Mittleren Hellenismus bis in die Mittlere Kaiserzeit (ca. 200 v. Chr. bis 150 n. Chr.). Wiesbaden 2010.

Ladstätter S. (2005). "Keramik". Ed. H. Thür, Hanghaus 2 in Ephesos, Die Wohneinheit 4. Baubefund, Ausstattung, Funde, FiE 4 8/6 (2005) 230-358.Wien.

Ladstätter S. (2008). "Funde". Ed. M. Steskal \& M. La Torre, Das Vedius Gymnasium in Ephesos, FiE 14/1 (2008) 97-189. Wien.

Ladstätter S. (2010). "Keramik". Ed. F. Krinzinger, Hanghaus 2 in Ephesos, Die Wohneinheiten 1 und 2. Baubefund, Ausstattung, Funde, FiE 8/8/1 (2010) 172-279. Wien.

Ladstätter S. (2014). "Keramik". Eds. H. Thür \& E. Rathmayr, Hanghaus 2 Wohneinheit 6, FiE, 8/9 (2014) 431-588. Wien.

Lamboglia N. (1962). "Punti fermi sul teatro romano di Ventimiglia". RStLig 28 (1962) 270-290.

Mayet F. (1975). Les céramiques a parois fines dans la Péninsule Ibérique. Paris 1975.

Mayet F. (1980). "Les ceramiques a parois fines: Etat de la question". Ed. P. Bruneau, Ceramiques hellenistiques et romaines (Annales litterai res de l'Universite de Besancon 242). Paris. (1980) 201-229.

Meriç R. (2002). Späthellenistisch-Römische Keramik und Kleinfunde aus einem Schachtbrunnen am Staatsmarkt in Ephesos, FiE 9/3. Wien 2002.

Meyer-Schlichtmann C. (1988). Die pergamenische Sigillata aus der Stadtgrabung von Pergamon: Mitte 2. Jh. v. Chr.-Mitte 2. Jh. n. Chr. PF 6. Berlin/NewYork 1988.

Mitsopoulos-Leon V. (1991). Die Basilika am Staatsmarkt in Ephesos: Kleinfunde 1. Keramik Hellenistischer und Römischer Zeit. FiE 9/2/2. Wien 1991

Moevs M. T. M. (1973). The Roman Thin Walled Pottery: From Cosa (1948-1954). MemAmAc 32. Rome 1973.

Niewöhner P. et al. (2015a). "Die Südstadtthermen von Milet". AA 2015/1 (2015) 173-235.

Niewöhner P. et al. (2015b). "Die Bischofspalast von Milet". AA 2015/2 (2015) 181-273.

Niewöhner P. (2016). "An Ancient Cave Sanctuary Underneath the Theatre of Miletus, Beauty, Mutilation, and Burial of Ancient Sculpture in Late Antiquity, and the History of the Seaward Defences". AA 2016/1 (2016), 67-156.

Outschar U. (1996). "Dokumentation Exemplarisch Ausgewaehlter Fundkomplexe". Eds. C. LangAuinger et. al., Hanghaus 1 in Ephesos: der Baubefund. FiE 8/3 (1996) 27-85. Wien.

Özyiğit Ö. (1990). “1989 yılı Phokaia Kazı Çalışmaları”. KST XII/1(1990) 127-153.

Özyiğit Ö. (1991). “1990 yılı Phokaia Kazı Çalışmaları”. KST XIII/1(1991) 99-122.

Pirson F. et al. (2015). "Pergamon, Bericht über die Arbeiten in der Kampagne 2014”. AA 2015/2 (2015) 89179.

Pülz S. (1985). “Milet 1983-1984: Kaiserzeitliche Keramik aus dem Heroon III”. IstMitt 35(1985) 77-99.

Pülz S. (1986). "Milet 1985. Ein Keramikkomplex der mittleren Kaiserzeit aus dem Heroon I". IstMitt 36 (1986) 13-20.

Pülz S. (1987). “Zwei Keramikkomplexe aus dem Heroon III”. IstMitt 37 (1987) 34-69.

Ricci A. (1985). "Ceramica A Pareti, Sottili”. Atlante delle Forme Ceramiche 2 (1985) 231-358, Lev. 78114. Roma.

Rizzo G. (2003). Instrumenta Urbis I. Ceramiche fine da mensa, lucerne ed anfore a Roma nei primi due secoli dell'impero. Roma 2003.

Robinson H. S. (1959). Pottery of the Roman Period: Chronology. Agora 5. Princeton 1959.

Rosser J. (1985). "Excavations at Saranda Kolones Paphos". DOP 39 (1985) 81-97.

Rotroff S. I. (1997). Hellenistic Pottery: Athenian and Imported Wheelmade Table Ware and Related Material. Agora 29. Princeton 1997.

Sackett L. H. (1992). Knossos: From Greek City to Roman Colony. Excavations at the Unexplored 
Mansion. London 1992.

Schindler-Kaudelka E. (1975). Die dünnwandige Gebrauchkeramik vom Magdalensberg. Klagenfurt 1975. Slane K. W. (1990). The Sanctuary of Demeter and Kore 2. The Roman Pottery and Lamps. Corinth 18/2. Princeton 1990

Vapur Ö. (2011). "Menderes Magnesiası Theatron Kazısı Seramik Buluntuları". Anadolu 31 (2011) 143-193.

Vegas M. (1963). "Vorlaufiger Bericht über Römische Gebrauchskeramik aus Pollentia (Mallorca)". BJb 163 (1963) 275-304.

Waldner A. \& Ladstätter S. (2014). "Keramik”. Eds. H. Thür \& E. Rathmayr, Hanghaus 2, Die Wohneinheit 6. Baubefund, Ausstattung, Funde, FiE 4/8/6 (2014) 435-588. Wien.

Wintermeyer U. (2004). Die Hellenistische und frühkaiserzeitliche Gebrauchskeramik auf Grundlage der Stratifizierten Fundkeramik aus dem Bereich der Heiligen Strasse. Mainz am Rhein 2004. 
